University of Pennsylvania Carey Law School

Penn Carey Law: Legal Scholarship Repository

Faculty Scholarship at Penn Carey Law

5-18-2015

\title{
The New Synthesis of Bank Regulation and Bankruptcy in the Dodd-Frank Era
}

David A. Skeel Jr.

University of Pennsylvania Carey Law School

Follow this and additional works at: https://scholarship.law.upenn.edu/faculty_scholarship

Part of the Banking and Finance Law Commons, Bankruptcy Law Commons, Business Law, Public Responsibility, and Ethics Commons, Economic Policy Commons, Finance Commons, Finance and

Financial Management Commons, Law and Economics Commons, Policy Design, Analysis, and Evaluation Commons, and the Political Economy Commons

\section{Repository Citation}

Skeel, David A. Jr., "The New Synthesis of Bank Regulation and Bankruptcy in the Dodd-Frank Era" (2015). Faculty Scholarship at Penn Carey Law. 1564.

https://scholarship.law.upenn.edu/faculty_scholarship/1564

This Book Chapter is brought to you for free and open access by Penn Carey Law: Legal Scholarship Repository. It has been accepted for inclusion in Faculty Scholarship at Penn Carey Law by an authorized administrator of Penn Carey Law: Legal Scholarship Repository. For more information, please contact PennlawIR@law.upenn.edu. 
Draft: 18 May 2015

\title{
The New Synthesis of Bank Regulation and Bankruptcy in the Dodd-Frank Era
}

\author{
David Skeel $^{1}$
}

\section{Introduction}

Although they briefly came together during the S\&L crisis of the 1980s—creating serious frictions as they did-banking and bankruptcy have long occupied nonoverlapping magisteria in the United States, with separate regulators, starkly different insolvency resolution processes and divergent terms for some of the same creditors and claims. ${ }^{2}$ When a commercial bank fails, bank regulators determine how the failure will be resolved, exercising broad discretion that is subject to very little second guessing. In bankruptcy, by contrast, the parties themselves make many of the key decisions, the process is slower and more transparent, and priority rules are more closely adhered to.

Since the enactment of the Dodd-Frank Act in 2010, bank regulation and bankruptcy have become far more closely intertwined. Thanks to the powers they are given under Title IIalso known as the Orderly Liquidation Authority_bank regulators now can take over the holding company of a systemically important financial institution ("SIFI”) and nearly any of its subsidiaries, not just its commercial banking subsidiaries. Dodd-Frank thus has significantly expanded the domain of the administratively oriented bank resolution process. Yet Title I of Dodd-Frank-- which gives bank regulators the power to designate SIFIs and subject them to special regulation-requires the SIFIs to produce "living wills" explaining how the SIFI could be

1 S. Samuel Arsht Professor, University of Pennsylvania.

2 One obvious illustration: derivatives are defined as "qualified financial contracts" in banking, and as "swaps" in bankruptcy. 
resolved in bankruptcy, not under Title II. And Title II prohibits bank regulators from invoking their new resolution powers unless they first determine that bankruptcy would not be effective.

Additional frictions arise in the specific details of Title II, which depart from bankruptcy law at key junctures. The rules that apply to derivatives and financial contracts if regulators invoke Title II are quite different than the rules in bankruptcy, for instance; and Title II requires that a SIFI's managers be ousted whereas bankruptcy does not. It is of course possible that the divergences between OLA and bankruptcy are warranted. At the very least, however, the inconsistencies underscore the need to consider whether the new synthesis of bank regulation and bankruptcy is coherent, and whether it is likely to prove effective. That is the task that I attempt to undertake in this chapter.

I will begin (in Parts I and II) by exploring some of the basic differences between bank resolution, which is a highly administrative process in the U.S., and bankruptcy, which relies more on courts and the parties themselves. For the purposes of this comparison, I will consider how the two insolvency frameworks address four basic issues: ensuring timely initiation of insolvency proceedings, allocating losses among shareholders and creditors, maximizing the value of the firm's assets, and minimizing any externalities of the insolvency process. The striking differences between bank resolution's and bankruptcy's handling of these issues raises the question why bank resolution is so different than ordinary bankruptcy, and whether its deviations from ordinary rule of law principles are justified. I conclude that they are, at least for small and medium-sized banks whose balance sheets are dominated by deposit liabilities.

My second general focus in the chapter (Parts IV, V, and VI, after a brief overview of the new Dodd-Frank synthesis in Part III) is on a series of remarkable new innovations designed to facilitate the rapid recapitalization of a troubled financial institution. The first, which would take effect outside of any resolution or bankruptcy process, is convertible contingent capital securities, or CoCos. CoCos are not a new idea, and they remain rare in the United States, but their use is rapidly expanding in Europe. I focus primarily on the question of how best to structure the trigger that would convert a CoCo into equity, endorsing the early trigger advocated by Charles Calomiris, Richard Herring and others. Although I am optimistic about the potential 
effectiveness of CoCos, I conclude that they are best seen as a supplement to the formal resolution and bankruptcy frameworks, not a replacement for them.

Turning to resolution and bankruptcy, I describe and critique the single point of entry strategy for recapitalizing SIFIs in Title II, which the Federal Deposit Insurance Corporation has devised in the past four years, and an even more recent proposal to use an analogous technique in Chapter $11 .^{3}$ Since single point of entry and the bankruptcy alternative lie at the heart of current thinking about the new synthesis, I explore each at some length. As we shall we, although both have significant limitations, and the bankruptcy alternative would require several amendments to the Bankruptcy Code, they hold genuine promise.

I conclude the chapter by assessing (in Part VII) the general coherence of the new synthesis. Some commentators have argued that Title I and Title II have inconsistent objectives, with Title I attempting to remove the risk that a SIFI will default, based on an assumption that the largest financial institutions are too big to fail, while Title II requires regulators to shut down a troubled SIFI. The advent of single point of entry has significantly diminished the force of this objection. The remaining concerns about coherence lie not within Dodd-Frank itself, but in the relationship between Title II of Dodd-Frank and bankruptcy—or so I will argue.

\section{Bank Insolvency and Bankruptcy: A Brief Comparison}

To begin our consideration of the new regulatory synthesis, it may be useful to briefly describe the somewhat different answers that traditional bank insolvency law and the Bankruptcy Code give to the core questions that insolvency law must address. For present purposes, we can group many of the key issues into four basic categories: initiation of the insolvency proceedings; maximizing the value of the debtor's assets; determining which obligations to restructure and to

\footnotetext{
3 A working group (of which I am a member) at the Hoover Institution has developed the most detailed proposal for implementing the bankruptcy strategy, which the group calls Chapter 142.0 or the "quick sale” strategy. Chapter 142.0 revises and supplements the group's earlier proposal for a new Chapter 14, a set of amendments to the Bankruptcy Code that are designed to enhance its effectiveness for SIFIs. See Thomas H. Jackson, Bankruptcy Code Chapter 14: A Proposal, in BANKRUPTCY NOT BAILOUT: A SPECIAL CHAPTER 14, at 25 (Kenneth E. Scott \& John B. Taylor, eds., 2012).
} 
what extent; and minimizing the spillover effects of the insolvency proceeding on third parties. In the discussion that follows, I briefly describe each, and note how bankruptcy and bank insolvency law address them. ${ }^{4}$

The first issue is ensuring that insolvency proceedings are triggered in a timely fashion. ${ }^{5}$ Because insolvency proceedings do not hold much upside for them, the managers of a troubled firm may delay initiating these proceedings. Considerable value may be destroyed as the firm's financial fortunes deteriorate. Chapter 11 addresses this concern by permitting the firm's current managers to continue running the business after it files for bankruptcy, rather than requiring that they immediately be displaced. The soft landing reduces managers' disincentive to file for bankruptcy. ${ }^{6}$

Banking regulation looks to bank regulators rather than bank managers to make the initiation decision. Although regulators' relationship to a bank is quite different than managers', they too have a tendency to wait too long to trigger insolvency proceedings. According to the conventional wisdom, which is confirmed by historical patterns, regulators have an incentive to postpone intervention so that the consequences will be borne by future regulators. ${ }^{7}$ To encourage more timely initiation, Congress enacted “prompt corrective action” requirements after the savings and loan crisis of the 1980s. The prompt corrective action rules require regulators to intervene in increasingly intrusive fashion as a bank’s financial condition deteriorates. $^{8}$

4 These issues are addressed in somewhat more detail in DAVID SKEEL, THE NEW FINANCIAL DEAL: UNDERSTANDING THE DODD-FRANK ACT AND ITS (UNINTENDED) CONSEQUENCES (2010). 5 The best and most complete analysis of initiation issues in the bankruptcy literature is Douglas G. Baird, The Initiation Problem in Bankruptcy, 11 INT’L REV. L. \& ECON. 223 (1991).

${ }^{6}$ In the 1980s and early 1990s, deviations from absolute priority that resulted in recoveries for shareholders in many Chapter 11 cases may also have contributed to the soft landing for managers, since managers generally hold significant amounts of stock. See, e.g., Thomas H. Jackson \& Robert E. Scott, On the Nature of Bankruptcy: An Essay on Bankruptcy Sharing and the Creditors' Bargain, 75 VA. L. REV. 155 (1989). But see Barry E. Adler, Bankruptcy and Risk Allocation, 77 CORNELL L. REV. 439 (1992)(pointing out that the soft landing may distort decision making incentives). But stockholders currently are less likely to receive a recovery.

7 See, for example, Jonathan R. Macey \& Geoffrey P. Miller, Kaye, Scholar, FIRREA, and the Desirability of Early Closure: A View of the Kaye, Scholer Case from the Perspective of Good Regulatory Policy, 66 S. CAL. L. REV. 1115, 1140 (1993).

8 For a brief overview of the requirements, see David A. Skeel, Jr., The Law and Finance of Bank and Insurance Insolvency Regulation, 76 TEX. L. REV. 723, 740-41 (1998). 
The second issue is maximizing the value of the debtor's assets. According to the best known normative theory of bankruptcy — the creditor's bargain theory —an effective insolvency regime addresses this concern by providing a collective forum for determining whether the assets should be reorganized or liquidated. ${ }^{9}$ The automatic stay brings a halt to the "race to the courthouse" that could lead to the dismembering of an otherwise viable firm, and Chapter 11's voting rules give creditors a voice in the decision of how to allocate the debtor's assets. The Bankruptcy Code includes a variety of other provisions that are designed to enhance liquidity during the bankruptcy. ${ }^{10}$

As with initiation, bank insolvency law leaves the asset allocation decision in the hands of bank regulators. Regulators have broad discretion how best to resolve a bank's financial distress, subject to the general statutory command that they choose the strategy that will best protect the deposit insurance fund. In a substantial majority of resolutions, the FDIC identifies a buyer for some or all of the bank’s assets, and resolves the bank through a purchase and assumption transaction that takes place after the close of business on Friday and is completed before the end of the weekend. ${ }^{11}$

The third issue is the restructuring of the debtor's obligations. If creditors expect to bear losses in the event the firm fails into financial distress, they will have an incentive to monitor the debtor; by contrast, if debtors are confident they will be bailed out, they may be too willing to lend and have too little incentive to monitor the debtor. ${ }^{12}$

The Bankruptcy Code assumes that creditors will bear losses, and allocates them according to a soft version of the absolute priority rule. If a class of creditors objects to a proposed reorganization plan that will not pay the class in full, no lower priority class of creditors is permitted to receive anything. ${ }^{13}$ A class of creditors can waive its right under the

9 See THOMAS H. JACKSON, THE LOGIC AND LIMITS OF BANKRUPTCY LAW (1986).

10 For discussion of bankruptcy's liquidity-enhancing features, see Kenneth Ayotte \& David A. Skeel, Jr., Bankruptcy Law as a Liquidity Provider, 80 U. CHI. L. REV. 1557 (2013).

11 See generally CLIFFORD CHANCE, LEGAL ASPECTS OF BANK BAIL-INS 6 (2011).

12 For detailed discussion, see Kenneth Ayotte \& David A. Skeel, Jr., Bankruptcy or Bailouts?, 35 J. CORP. L. 469, 495 (2009).

1311 U.S.C. 1129 (b). 
absolute priority rule, however, by agreeing to a proposed reorganization that deviates from strict absolute priority. ${ }^{14}$

The bank priority scheme differs in several significant ways. First, and most importantly, it fully protects up to $\$ 250,000$ in deposits even though depositors traditionally would have been general unsecured creditors. ${ }^{15}$ This protection is intended to discourage depositor runs. The protection against runs is thought to outweigh the risk of moral hazard created by the assurance that depositors will be paid in full. Second, bank insolvency law authorizes the FDIC to alter the priority rules.

The final objective is minimizing the potential externalities of the insolvency process. The concern that the insolvency framework may have effects on third parties was the principal justification for exempting derivatives, repurchase agreements and other financial contracts from the automatic stay and other core bankruptcy provisions. ${ }^{16}$ If derivatives counterparties were subject to the automatic stay, the reasoning went, the counterparty's stability might be jeopardized by the delay in enforcing its contractual rights, and this might bode ill for the counterparties’ counterparties. In banking, concern for spillover effects figures even more strongly. In addition to protecting depositors, bank insolvency law explicitly authorizes bank regulators to take systemic risks into account in its bank resolutions.

Overall, bank resolution is much more discretionary and does not honor rule of law virtues such as transparency and clear priorities. It also is more concerned with curbing potential spillover effects. ${ }^{17}$

14 The absolute priority rule in section 1129(b) only applies to classes that have not voted in favor of the plan.

15 I say "traditionally" because U.S. law also has given priority to U.S. (but not foreign) deposit claims since the enactment of the National Depositor Preference statute in 1993. 12 U.S.C. § 1821(d)(11)(A).

16 See, e.g., David A. Skeel, Jr. \& Thomas H. Jackson, Transaction Consistency and the New Finance in Bankruptcy, 112 COLUM. L. REV. 152 (2012); Mark J. Roe, The Derivatives Market's Payment Priorities as Financial Crisis Accelerator, 63 STAN. L. REV. 539 (2011); Franklin R. Edwards \& Edward R. Morrison, Derivatives and the Bankruptcy Code: Why the Special Treatment?, 22 YALE J. REG. 92 (2005).

17 For discussion of this last point, see Randall D. Guynn, Are Bailouts Inevitable?, 29 YALE J. on REG. 121 (2012). 


\section{Why is Bank Insolvency Law Separate?}

As the overview in the last part made clear, bank insolvency is subject to a different regulatory framework and has addressed the core questions quite differently than the bankruptcy laws that apply to other firms. This raises the question why bank insolvency is regulated separately and whether this is inevitable or desirable.

The first thing to note is that only the commercial banking subsidiary itself is excluded from bankruptcy. ${ }^{18}$ Many banks—especially large and medium-sized banks_—are part of a bank holding company framework. A systemically important financial institution like Citigroup or J.P. Morgan Chase may consist of a holding company, commercial banking subsidiaries, investment banking subsidiaries, and subsidiaries of other kinds. If the SIFI fell into financial distress, the holding company could file for bankruptcy, as could the investment banking subsidiaries and other subsidiaries (except insurance subsidiaries). ${ }^{19}$ Only the commercial bankruptcy subsidiaries are barred from bankruptcy.

One answer to the question why bank insolvency law is separate is historical. The earliest American bankruptcy laws did not always distinguish between banks and other firms. Only during the Civil War era did bank regulation and the regulation of other firms decisively part ways. This suggests that separation may have been historically contingent rather than inevitable. Indeed, in some countries, such as the United Kingdom, banks are subject to the same insolvency framework as other businesses. ${ }^{20}$

The observation that the hiving off of bank insolvency regulation from bankruptcy does not appear to have been inevitable deepens the question of whether it is desirable. Is it? The conventional answer is yes_-that banks need a special, administrative insolvency framework

1811 U.S.C. § 109(b)(excluding commercial banks and insurance companies from Chapter 7); 11 U.S.C. 109(d)(excluding persons and entities that cannot file for Chapter 7 from Chapter 11).

1911 U.S.C. § 109(b)(excluding insurance companies from Chapter 7). One other important qualification is that investment banks can file for Chapter 7 but cannot file for Chapter 11. 11 U.S.C. § 109(d)(excluding "stockbroker" or "commodity broker" from Chapter 11).

${ }^{20}$ See generally THOMAS F. HUERTAS, SAFE TO FAIL: HOW RESOLUTION WILL REVOLUTIONISE BANKING (2014). 
because bank resolution needs to take place extremely quickly to preserve the value of bank assets, to assure that depositors have continuous access to their deposits, and to prevent disruptions to the payment system. Given its ongoing involvement in oversight, the FDIC is well-positioned to intervene quickly, and bank insolvency law gives the FDIC the flexible authority it needs to achieve an effective resolution. By contrast, a bankruptcy judge would have no particular expertise or knowledge about a bank prior to its failure, and the bankruptcy process is too slow, requiring that creditors be notified and given the opportunity to object before a firm's assets could be sold or other major decisions made. ${ }^{21}$

It is perhaps worth noting that these benefits do not require the separate treatment of bank insolvency and bankruptcy. Lawmakers could incorporate the administrative features of bank resolution into a bankruptcy law if they wished, giving bank regulators the same powers in bankruptcy that they currently have under bank insolvency law. But the current bank insolvency framework is administrative in nature, whereas the bankruptcy laws leave much more of the process to the parties themselves. Relatedly, the bank insolvency process emphasizes administrative flexibility rather than rule of law virtues such as clear rules and transparency, whereas the bankruptcy rules place more emphasis on rule of law virtues.

The FDIC's sweeping discretion leaves a bank's non-depositor creditors with very little protection. In theory, a disgruntled creditor can challenge either the resolution or the FDIC's treatment of its particular claim. But such a challenge is fraught with obstacles. Because the FDIC acts secretly, creditors cannot question an FDIC action in advance. Any challenge must thus come after the fact. Moreover, the banking laws constrain the grounds for recovery in important respects-limiting it to damages, for instance, and to the difference between the claimant's payout and its likely treatment in a liquidation — and the FDIC's determinations are given de facto deference. In the words of one former FDIC official, in an email to one of my coauthors, "there are few cases and changes in the outcome are rare."22

21 See, e.g, Guynn, supra note

22 Email correspondence from William Kroener to Thomas Jackson (August 2010). 
Despite these shortcomings, the current framework is probably worth retaining. First, preserving continuous access to deposits and the payment system are indeed important concerns. Although these benefits could be replicated in a framework that paid more heed to rule of law virtues, the quick, secretive FDIC process achieves these objectives effectively.

Second, and more importantly, the vast majority of the liabilities of small and mediumsized banks are deposits (and deposits are entitled to first priority, thanks to a depositor preference law enacted in 1993). More than 96\% of the liabilities of banks with less than $\$ 100$ million in assets that failed between 1995 and 2009 were deposits. ${ }^{23}$ For banks with between $\$ 100$ and $\$ 500$ million in liabilities the percentage was $92.85 \%$; it was roughly $88 \%$ for banks up to $\$ 5$ billion. ${ }^{24}$ Because deposits make up such a large percentage of a bank’s liabilities, and because the FDIC is responsible for making sure that depositors are paid, it makes sense to let the FDIC decide what to do with the bank's assets. The FDIC and the deposit insurance fund are, in a sense, the only creditors with a real interest in the outcome. Even if the FDIC does not handle the resolution effectively, the harm to the bank's other creditors (or the windfall, in the event the FDIC decides to protect them) is quite limited in most cases. ${ }^{25}$

Notice how context-specific this endorsement of the bank insolvency framework is. When banks' liabilities are nearly all deposits, and the government has guaranteed the deposits, the case for an administrative resolution framework is strong. For banks and other financial institutions that do not fit this profile—as the largest holding companies do not—administrative resolution needs to be justified on other grounds. It does not make sense to argue, as advocates of the new Dodd-Frank resolution rules did, that the FDIC's seventy-five year track record resolving small and medium-sized banks tells demonstrates the virtues of expanding administrative resolution to the largest financial institutions. ${ }^{26}$ This observation will prove

23 These figures are cited in Richard Hynes \& Steven Walt, Why Banks are Not Allowed in Bankruptcy, 67 WASH. \& LEE L. REV. 985 (2010).

24 Id.

25 Hynes and Walt reach a similar conclusion. Id.

26 This theme was emphasized in the White Paper that served as the original foundation for the Dodd-Frank Act, see U.S. DEPT. OF TREASURY, FINANCIAL REFORM: A NEW FOUNDATION 76 (June 2009), and repeated throughout the legislative debates. 
important as we explore Dodd-Frank's reconfiguration of banking regulation and the ways the new rules are being worked out.

\section{Dodd-Frank’s Reconfiguration of Banking Regulation}

As noted in the last part, prior to the Dodd-Frank Act, bank regulators had nearly unbridled discretion to resolve a failed commercial bank, but no particular insolvency authority over the other entities in a bank holding company structure. In this part, I begin by describing the pre-Dodd-Frank structure in slightly more detail. I then show how the Dodd-Frank Act reconfigured the regulatory framework, highlighting several underappreciated features of the new rules.

\section{A. Bank and Bank Insolvency Regulation before Dodd-Frank}

To appreciate the pre-Dodd-Frank structure, consider the largest bank holding companies. A holding company like Citigroup or J.P. Morgan Chase has a parent corporation, commercial banking subsidiaries, investment banking subsidiaries, insurance subsidiaries, and numerous other subsidiaries including (especially prior to Dodd-Frank) interests in hedge funds and other funds. ${ }^{27}$ The different entities are subject to a variety of different regulators. The Federal Reserve regulates the holding company. Commercial banks may be regulated either by state regulators or, if it is a federal bank, the Office of the Comptroller of the Currency.

If a giant financial institution fell into financial distress prior to Dodd-Frank, the holding company itself and any subsidiary other than a commercial bank or insurance company could file for bankruptcy. As noted earlier, most of these subsidiaries could file either in Chapter 11, which generally contemplates reorganization, or Chapter 7 , which provides for liquidation. The principal exception is investment banks, which can file for Chapter 7 but are not permitted to file

27 The Volcker Rule enacted as part of the Dodd-Frank Act has sharply reduced the stake a bank holding company can hold in hedge funds or equity funds. Dodd-Frank Act § 619 (12 U.S.C. § 1851)(limiting holdings to 3\% of fund). 
for Chapter 11. The exclusion of investment banks from Chapter 11—which now seems anachronistic - explains why Lehman Brothers' holding company and some of its subsidiaries filed for bankruptcy on September 15, 2008, but its investment banking subsidiary did not. ${ }^{28}$

Commercial banks and insurance companies are both excluded from bankruptcy. If a commercial bank falls into distress, either the FDIC or a state regulator can initiate insolvency proceedings; and the FDIC steps in as receiver (or much less often, conservator). Insurance insolvency is handled by state insurance regulators.

When a bank holding company files for bankruptcy, bank regulators have much less regulatory authority over the bankruptcy proceedings than they would in a bank resolution. This caused great consternation during the Savings \& Loan crisis of the late 1980s. In a number of cases, bank regulators insisted that the holding company needed to serve as a "source of strength” for its commercial bank subsidiary after the holding company filed for bankruptcy, but the holding company refused, insisting that its principal responsibility was to the holding company's own creditors and shareholders. Bank regulators won a partial victory in the Supreme Court's MCorp decision, although the Court concluded that it did not need to explicitly determine the legitimacy of source of strength. ${ }^{29}$

After the 2008 crisis, bank regulators once again complained about the limitations of their authority. Henry Paulson, Ben Bernanke and Timothy Geithner-who were the Treasury Secretary, Federal Reserve Chair and President of the New York Federal Reserve at the timehave each insisted that they were precluded by the constraints on emergency Federal Reserve intervention from rescuing Lehman Brothers. ${ }^{30}$ Although these post-crisis statements appear to have been revisionist history, enhancing bank regulators' ability to take control of the entire bank

28 See, e.g., David A. Skeel, Jr., Bankruptcy Boundary Games, 4 BROOK. J. CORP., FIN. \& COMM’L L. 1, 3-6 (2009)(criticizing the exclusion of investment banks).

29 Board of Governors v. MCorp Financial, Inc., 112 S.Ct. 459 (1991). For a useful contemporaneous discussion of MCorp, see Craig L. Brown, Note, Board of Governors v. MCorp Financial, Inc.: Evaluating the Source-of-Strength Doctrine, 21 HOFSTRA L. REV. 235 (1992). Congress codified source of strength in the Dodd-Frank Act. DoddFrank Act $\S 616$.

30 See, e.g., HENRY PAULSON, ON THE BRINK. 
holding company structure — not just the commercial bank subsidiaries—was a central aim of the Dodd-Frank financial reforms.

\section{B. The Dodd-Frank Framework}

The Dodd-Frank reconfiguration of the pre-crisis regulatory framework has two major parts, each aimed at systemically important financial institutions. ${ }^{31}$ In addition to creating a new financial regulator - the Federal Systemic Oversight Council, comprised of the heads of the major financial regulators ${ }^{32}$-Title I singles out systemically important financial institutions for heightened capital requirements and regulatory oversight. A bank holding company that has $\$ 50$ billion or more in assets automatically qualifies as systemically important for the purposes of Title I. In addition to these banks, FSOC has the authority to designate other financial institutions as systemically important. As of this writing, FSOC has designated AIG, GE Capital, Prudential, and Metropolitan Life, and has promulgated a rule outlining a set of considerations that informs its determinations. ${ }^{33}$

Title I requires each of the financial institutions subject to its enhanced oversight to prepare an annual "rapid resolution plan"—or living will—explaining how it could be resolved without causing systemic damage in the event it fell into financial distress. ${ }^{34}$ Title I also authorized regulators to force bank holding companies with more than $10 \%$ of the nation's deposit liabilities to downsize if there is a danger of systemic harm, ${ }^{35}$ and instructed regulators to prepare studies of contingent capital securities and repurchase agreements. ${ }^{36}$

Dodd-Frank's other major contribution comes in Title II, which houses the new rules for resolving systemically important financial institutions. The U.S. Treasury is the quarterback of

\footnotetext{
31 The discussion that follows draws from SKEEL, THE NEW FINANCIAL DEAL, supra note _, which describes the framework in more detail.

32 Dodd-Frank Act § 111.

33 CITE. GE Capital is shedding its financing operations, at least in part to extricate itself from designation under Title I. Met Life currently is litigating its designation.

34 Dodd-Frank Act § 165(d).

35 Id. § 121 [check].

36 Id. $\S 115(\mathrm{c})$.
} 
the new resolution process. If the Treasury, backed by two-thirds votes of the Federal Reserve Board of Governors and the FDIC board, concludes that a financial company is on the verge of default, or has defaulted, and that its failure “would have serious adverse effect on financial stability in the United States,” it can trigger resolution by filing a petition in federal court in Washington, D.C. ${ }^{37}$ Judicial review is extremely limited. So long as it was not "arbitrary and capricious for regulators to determine that the company was in danger of default, the court must sign off on the petition. ${ }^{38}$ If Treasury persuades the company to accept the petition, it can avoid review altogether.

If the petition is approved, the FDIC is appointed receiver (other than with investment banks, where the SEC is receiver), and is given extensive authority to borrow money and to take over the company's operations during the receivership. Under the Orderly Liquidation Fund provisions of Title II, the FDIC can borrow up to $10 \%$ of the pre-resolution asset value of the troubled institution or $90 \%$ of the fair value of its assets in resolution from the U.S. Treasury, no questions asked. ${ }^{39}$

Lest resolution have the appearance of a pleasant landing, the FDIC is instructed to kick out any managers of the company who were "substantially responsible for its financial distress," to wipe out shareholders' interests, and to impose losses on creditors whose claims are not assumed. ${ }^{40}$ Unlike ordinary bank resolution, which permits the FDIC to reorganize a bank through a "conservatorship,” Title II provides only for receivership, which in bank resolutions under the FDI Act is nearly always used to liquidate the troubled bank. A late amendment proposed by Senator Barbara Boxer added an exclamation point, stating that any company in resolution must be liquidated. ${ }^{41}$

One somewhat surprising feature of the Title II resolution rules is the absence of a formal relationship between Title II resolution and Title I oversight. It would be natural to assume that
Id. § 202.
Id.
Id. § 210(n).
Id. 206.
1 Id. § 214. 
regulators cannot put a financial institution into Title II unless it has first been identified as systemically important for the purposes of Title I. But there is no explicit connection between the two titles. Any financial company-that is, a company that derives at least $85 \%$ of its earnings from financial activities ${ }^{42}$ — can be labeled as a "covered company" and thrown into resolution if the regulators believe that its default would cause financial instability. Surely the two sets of companies will overlap significantly, but regulators' failure to have designated a company as systemically important for the purposes of Title I does not preclude them from subjecting it to a Title II resolution.

Equally surprising is the relationship between Title II resolution and bankruptcy. Despite regulators' profound distrust of bankruptcy in 2008, both Title I and Title II strongly emphasize that bankruptcy should be the insolvency framework of first resort. The Dodd-Frank Act signals its preference for bankruptcy at two key junctures. First, under Title I’s living will requirement, systemically important financial institutions must explain how their financial distress could be resolved in bankruptcy without causing systemic harm. ${ }^{43}$ Bankruptcy is the focus, not resolution under Title II. Second, before invoking Title II, regulators must first determine that the troubled financial institution cannot be resolved effectively in bankruptcy. ${ }^{44}$ Once again, the Dodd-Frank Act instructs regulators to focus first on bankruptcy.

The principal limitation of this robust endorsement of bankruptcy is that regulators' authority to invoke Title II would trump bankruptcy if regulators wished to invoke their Title II powers. Regulators are authorized to remove a financial institution from bankruptcy and put it in Title II at any time. Moreover, although the regulators must first conclude that the institution cannot be effectively resolved in bankruptcy, their conclusion that bankruptcy is not adequate is not subject to any judicial review at all. As noted earlier, the only issues that are subject to review are the questions whether the institution is a financial institution and whether it is in default or in danger of default.

42 Id. $\S 201$.

43 Dodd-Frank Act $\S 165(d)$.

44 Dodd-Frank Act § 203(b) prohibits regulators from invoking Title II unless the Secretary of the Treasury determines that "the failure of the financial company and its resolution under [other law, e.g., the Bankruptcy Code] would have serious adverse effects on financial stability in the United States.” 


\section{Key Limitations of Title II as Enacted}

As enacted, ${ }^{45}$ Title II's handling of each of the key resolution issues appeared to be seriously deficient. If Title II requires regulators to liquidate any institution they take over (as the "thou shalt liquidate" provision suggests), they would have a strong disincentive invoke it, especially with the largest financial institutions. And unlike ordinary bank insolvency law, the Dodd-Frank Act does not include any provisions that are designed to force regulators to intervene in a timely fashion. The managers of a troubled financial institution would have equally strong incentives to resist Title II, since Title II requires the removal of any who are “substantially responsible” for its decline.

Second, for those financial institutions that do wind up in bankruptcy, liquidation may not always maximize the value of the estate. For well over a century, American corporate bankruptcy law has assumed that some form of reorganization will often preserve more value for creditors than liquidation.

Third, while Title II does require that shareholders and creditors take losses, its priority rules apply only to creditors whose contracts regulators do not decide to fulfill. Shareholders would almost certainly be wiped out, but regulators have only one day to decide whether to assume the institution's derivatives contracts. It seems likely that regulators would assume most or all of the derivatives and pay them in full.

Finally, Title II does give regulators both the authority and the funding to ensure that a Title II resolution does not cause spillover effects. This is the one objective Title II is best designed to achieve. But the benefit would be quite limited if regulators were forced to liquidate any institution they took over, and thus had a strong disincentive to invoke Title II.

45 I say "as enacted" to distinguish the literal language of Title II from the single point of entry strategy discussed in Part V below. Single point of entry stands in tension with the literal language of Title II but is in my view a more promising strategy. 
An insolvency framework that calls for liquidation is not necessarily inefficient. The prospect of harsh treatment in bankruptcy can strengthen creditors' ability to monitor outside of bankruptcy. ${ }^{46}$ Where government regulators rather than creditors are the principal monitors, however, this approach is much less likely to be efficient. One solution to regulators’ shortcomings is to impose additional requirements that are designed to overcome their flawed incentives. This is the strategy reflected in the prompt corrective requirements in banking law. As it turns out, bank regulators have responded to the regulatory delay concern themselves, albeit in a very different way, adopting a recapitalization strategy known as single point of entry that is designed circumvent Title II's liquidation requirement. I turn to single point of entry below, after first considering another recapitalization strategy: contingent capital.

\section{The Contingent Convertible Capital Alternative}

For the past three decades, scholars have dreamed about approaches to bank insolvency that might make key features of the formal insolvency framework unnecessary. The most promising of these is the issuance of securities that would convert into equity in the event that a bank fell into financial distress. In the wake of the 2008 crisis, convertible contingent capital securities, or CoCos, are in wide circulation for the first time. In Europe, more than 100 billion euros of CoCos have been issued. After briefly describing the scholarly literature on these securities and their predecessors, I highlight the key design issues they raise and consider the relationship between these securities and the formal resolution rules.

During the S\& L crisis of the 1980s in early 1990s, several scholars proposed an early version of these contingent securities. Under the most prominent of the proposals, a bank would be required to issue a specified amount of puttable subordinated debt. ${ }^{47}$ Holders of puttable

\footnotetext{
46 See, e.g., David A. Skeel, Jr., An Evolutionary Theory of Corporate Law and Corporate Bankruptcy, 51 VAND. L. REV. 1325 (1998)(contrasting ex ante and ex post governance approaches). See also Barry E. Adler, A Theory of Corporate Insolvency, 72 N.Y.U. L. REV. 343 (1997)(demonstrating that capital structure arrangements designed to leave little salvageable value in the event of failure could be efficient).

47 See, e.g., Larry D. Wall, A Plan for Reducing Future Deposit Insurance Losses: Puttable Subordinated Debt, ECON. REV. (Federal Reserve Bank of Atlanta), July/Aug. 1989, at 2-3; Charles W. Calomiris \& Charles M. Kahn,
} 
subdebt could, and presumably would, put their debt back to the bank if its value fell below par. If lawmakers tied initiation to investors' exercise of their put options, insolvency proceedings might routinely be triggered as soon as a bank’s net worth fell below zero. ${ }^{48}$

In the corporate bankruptcy literature, Barry Adler proposed that corporations issue debt, which he called "chameleon equity," that would automatically convert to equity if the firm defaulted. ${ }^{49}$ Unlike the puttable subdebt proposal, which was designed to push troubled banks into insolvency, Adler's chameleon equity approach would recapitalize a troubled company after it had defaulted. If the company's distress were temporary, it might dramatically simplify the formal insolvency proceedings or even obviate the need for bankruptcy altogether. ${ }^{50}$

More recently, banking scholars have advocated that bank holding companies issue a very similar form of security that has become known as convertible contingent capital, or a CoCo. ${ }^{51}$ Like chameleon equity, CoCos would convert to equity as the bank holding company’s condition deteriorated. With CoCos, the conversion would come prior to a default. If effective, CoCos would quickly recapitalize a company, making formal resolution proceedings unnecessary.

The Role of Demandable Debt in Structuring Optimal Banking Arrangements, 81 AM. ECON. REV. 497, 500-01 (1991).

48 Puttable subdebt obviously would prove ineffective if regulators propped up the value of the subdebt by implicitly or explicitly promising a bailout in the event of distress, as was done with the biggest banks other than Lehman in 2008.

49 Barry E. Adler, Financial and Political Theories of American Corporate Bankruptcy, 45 STAN. L. REV. 311 (1993).

50 For a more complete description and critique of chameleon equity, see David A. Skeel, Jr., Markets, Courts, and the Brave New World of Bankruptcy Theory, 1993 WISC. L. REV. More recently, Adler has advocated that a similar approach be used in connect with the Dodd-Frank Act's living will requirement. Viral V. Acharya, Barry Adler, Matthew Richardson, and Nouriel Roubini, Resolution Authority, in REGULATING WALL STREET: THE DODD-FRANK ACT AND THE NEW ARCHITECTURE OF GLOBAL FINANCE 213, 235 (Viral V. Acharya et al, eds. 2011)(“In the event of an uncured default (after ample opportunity for cure) on a firm's debt obligation, the equity of the firm would be eliminated and the lowest-priority debt tranche would be converted to equity").

51 See, e.g., Charles W. and Richard J. Herring, How to Design a Contingent Convertible

Debt Requirement that Helps Solve Our Too-Big-To-Fail Problem, 25 J. APPLIED CORP. FIN. 21 (2013); Mark J. Flannery, “No Pain, No Gain”: Effecting Market Discipline via "Reverse Convertible Debentures,” in CAPITAL ADEQUACY BEYOND BASEL: BANKING, SECURITIES, AND INSURANCE (Hal Scott ed. 2005); Mark J. Flannery, Stabilizing Large Financial Institutions with Contingent Capital Certificates, Federal Reserve Bank of New York Working Paper (Oct. 5, 2009); Darrell Duffie, A Contractual Approach to Restructuring Financial Institutions, in ENDING GOVERNMENT BAILOUTS AS WE KNOW THEM (ed. George P. Schultz, Kenneth E. Scott, \& John B. Taylor, 2010). 
The most difficult design issue is the trigger: Should an administrative official decide when the CoCo converts to equity, or should a market signal such as a drop in the market value of the securities or a decline in bank capital trigger the conversion? Both approaches have significant downsides. Administrators often wait too long to intervene and may be subject to political pressures. Some market triggers may be subject to manipulation. Banks may have the ability to manipulate the amount of capital they report, for instance. If conversion is triggered by a decline in the market price of the CoCos, and the bonds would sharply diminish in value after conversion, the prospect of conversion could create a feedback effect that prevents the trigger from occurring. If the bonds will retain their value and significantly dilute the bank's common stock in the event of conversion, a stock price decline could snowball toward the conversion trigger and the trigger might invite manipulation. ${ }^{52}$

The most promising recent proposals rely on a market trigger that would occur much earlier in a bank's decline than the traditional approach. Charles Calomiris and Richard Herring propose, for instance, CoCos that would be triggered when the market value of a SIFI's equity, divided by the sum of the market value of the equity and the face value of its debt, dropped to eight percent. ${ }^{53}$ To avoid manipulation, Calomiris and Herring would base the value of the SIFI's equity on a 90-day moving average of its price. ${ }^{54}$ To ensure that the CoCos would significantly dilute the value of the SIFI's equity, thus giving its managers a strong incentive to avoid conversion by maintaining a strong equity buffer, Calomiris and Herring advocate that SIFI's be required to issue CoCos with a face amount equal to or greater than 10 percent of the book value of the SIFI's assets; and that the conversion ratio ensure that equity would be diluted by at least 5 percent. ${ }^{55}$ While many scholars would use the equity prices in their trigger, as

\footnotetext{
52 Relatedly, Sundaresan and Wang show that dilutative CoCos can in theory give rise to a multiple equilibria problem, in which two potential values of the bank's stock are potential equilibria, one reflected the value of the stock in the absence of conversion and the other reflecting its value after conversion. Suresh Sundaresan \& Zhenyu Wang, Design of Contingent Capital with Stock Price Trigger for Conversion, Working Paper (April 23, 2010). Their analysis assumes that the bank's managers will not take steps to forestall conversion, such as issuing new equity. Calomiris \& Herring, supra note _, at 52.

53 Calomiris and Herring call their ratio the "quasi-market-value-of-equity” ratio, or QMVER. Calomiris \& Herring, supra note _, at 47.

54 Id.

55 Id. at 50-51.
} 
Calomiris and Herring do, ${ }^{56}$ other scholars have proposed triggers based on credit default swap spreads. ${ }^{57}$

Although CoCos were largely hypothetical before the recent crisis, European banks have now issued 100 billion euros of CoCos. In Switzerland, regulators required the two largest banks, UBS and Credit Suisse, to issue CoCos due to concerns that the banks would "too big to save” if they failed. The Swiss vote of approval seems to have magnified the perceived legitimacy of CoCos.

In contrast to Europe, CoCos are still quite uncommon in the U.S. Why is this? The principal reason for SIFIs' failure to issue CoCos in the U.S. seems to be the disfavored tax and regulatory status of CoCos. Because CoCos convert to equity, they may not qualify as debt for tax purposes, which would preclude the issuing bank from deducting its interest payments on the CoCos. ${ }^{58}$ CoCos also do not receive favorable regulatory treatment for the purpose of the bank's capital requirements.

Suppose that these obstacles disappear once CoCoS fully take hold in Europe. How would they shape bank regulation and resolution? If bank SIFIs issued market-based CoCos, they might counteract the regulatory hesitancy that delayed intervention in 2008. Although Citigroup appeared to be insolvent, for instance, bondholders rightly assumed that regulators would not be willing to let Citigroup fail. ${ }^{59}$ If Citigroup had issued CoCo’s, the CoCos might

56 John Coffee advocates a two-part trigger consisting of the price of the SIFI's stock as well as a market index. John C. Coffee, Jr., Systemic Risk After Dodd-Frank: Contingent Capital and the Need for Regulatory Strategies Beyond Oversight, 111 COLUM. L. REV. 795, 841 (2011). Under Coffee's approach, the CoCo would convert to preferred stock with significant voting rights after conversion. Id. at 828-33. Coffee's proposal seems to parallel Calomiris and Herrings in many respects, but would introduce additional complications and is unspecified in many of its details.

57 See, e.g., Kent Smetters, CITE. Calomiris and Herring conclude that CDS spreads are "less desirable" as triggers, because the markets are somewhat thin and they price risk differently at different points in time. Calomiris \& Herring, supra note _, at 47.

58 John Coffee has argued that CoCos would in fact qualify as debt for tax purposes, since neither managers nor shareholders would wish for the conversion to occur. Coffee, supra note _, at 835-36.

59 Citigroup's travails before and during the crisis also illustrate the limitations of capital requirements as a gauge of a bank's condition. As Darrell Duffie has pointed out that Citibank "had a Tier 1 capital ratio that never fell below $7 \%$ during the crisis as $11.8 \%$ at roughly its weakest moment in December 2008, when the stock-market capitalization of Citibank's holding company fell to ... about 1\% of its total accounting assets.” Darrell Duffie, Contractual Methods for Out-of-Court Restructuring of Systemically Important Financial Institutions (2009)(memorandum for U.S. Treasury Working Group on Bank Capital). 
have triggered a recapitalization and possibly even avoided the need for the massive bailout that regulators funneled to Citigroup through the TARP program.

Even the best-designed CoCos would not serve as a substitute for a resolution framework, however, as advocates for CoCos acknowledge. "[I]f an institution waits too long [to replenish its equity],” as Calomiris and Herring put it, “or experiences a sudden, dramatic loss of market confidence (as in the Enron collapse), it may find that it can sell assets only at distressed prices."60 In the words of another advocate of CoCo's, contingent capital "is not presented as a panacea or as an adequate remedy by itself, but more as a failsafe, supplementary protection.” 61 A bankruptcy or resolution framework still is a necessary backstop. It is to these options of last resort, and how they fit together, that I now turn.

\section{The Single Point of Entry Strategy for Resolving SIFIs}

As enacted, Title II is a strategy for liquidating SIFIs that fall into financial distress. As we saw earlier, if a genuine liquidation were the only option under Title II, regulators would be extremely reluctant to use it. After Title II was enacted, the FDIC developed a more promising strategy for implementing Title known as single point of entry. ${ }^{62}$ Single point of entry would recapitalize a troubled SIFI rather than liquidating it. It is, in a sense, a more thorough-going version of the recapitalization that CoCos are designed to provide.

The new approach is called single point of entry because the holding company atop a financial institution's corporate structure would be put into receivership but most or all of the

60 Calomiris \& Herring, supra note —, at 46.

61 Coffee, supra note _, at 808.

62 For early descriptions of this strategy, before it was dubbed single-point-of-entry, see Guynn, supra note _, at 147-50; and comment letter from the Securities Industry and Financial Markets Association and The Clearing House Association to FDIC on its second notice of proposed rulemaking under Title II of the Dodd-Frank Act, May 23, 2011, http://www.fdic.gov/regulatios/laws/federal/2011/11c16Ad73.PDF. Douglas Baird and Ed Morrison also pointed out early on that Title II could be used to recapitalize a systemically important financial institution. See Douglas G. Baird \& Edward R. Morrison, Dodd-Frank for Bankruptcy Lawyers, 19 AM. BANKR. INST. L. REV. 287 (2011). The FDIC formally endorsed and outlined single-point-of-entry in Federal Deposit Insurance Corporation, The Resolution of Systemically Important Financial Institutions: The Single Point of Entry Strategy, 78 Fed. Reg. 76614 (Dec. 18, 2013). 
affiliated entities would not. ${ }^{63}$ The restructuring would occur primarily at the holding company level, with liquidity down-streamed to affiliates as necessary. In a single-point-of-entry resolution, the FDIC would transfer all of the holding company's assets, any short-term unsecured debt, and any secured debt to a newly created bridge institution. The holding company's stock and long-term unsecured debt would be left behind, leaving the bridge institution with a more sustainable capital structure. At some point thereafter, the FDIC would (probably) wipe out the old stock and would convert at least some of the long-term debt to stock in the bridge entity. If one or more subsidiaries were facing a solvency issue, the holding company could inject capital by converting obligations owed by the subsidiary to the bridge entity into stock or by contributing other holding company assets (including receivables from other subsidiaries) to the needy subsidiary. ${ }^{64}$

The single point of entry approach is far from foolproof, and I will consider some of its limitations below. But single point of entry is considerably more promising than the structure envisioned by the rules as enacted.

\section{A. Benefits of Single Point of Entry}

Start with the uncertainty whether and how regulators will intervene. ${ }^{65}$ With a welldefined single point of entry strategy in place, it is at least possible that regulators would invoke the resolution rules if a systemically important financial institution threatened to fail. The uncertainty would not be dispelled altogether, but it is more plausible that regulators would use Title II to effect a single-point-of-entry restructuring than it is that they would take over a giant financial institution and wind it down.

63 The strategy is outlined in detail in John Bovenzi, Randall Guynn, and Thomas Jackson, Too Big to Fail: The Path to a Solution 26-27 (Bipartisan Policy Center, May 14, 2013).

64 Id. at 27. If one or more subsidiaries continued to face a liquidity crisis after being recapitalized, the bridge entity theoretically could make a secured loan to the needy subsidiary and re-pledge the collateral received from the subsidiary to the FDIC in return for a matching secured loan from the FDIC's orderly liquidation fund (which is borrowed from the US Treasury).

65 For further discussion of the points raised in this section, see David Skeel, Single Point of Entry and the Bankruptcy Alternative, in ACROSS THE GREAT DIVIDE: NEW PERSPECTIVES ON THE FINANCIAL CRISIS (ed. John B. Taylor \& Martin Neal Baily 2014). 
Second, because single point of entry promises that the financial institution's derivatives and other short-term debt will be fully protected, it diminishes the likelihood of runs in the event a financial institution threatens to default. (There are costs as well as benefits to the protection of derivatives, but I save the costs for the next section.) The risk of runs will not disappear altogether; repo lenders may still refuse to roll over their repo loans, for instance. But single point of entry reduces the downside consequences of failure for a financial institution's shortterm creditors and as a result should dampen the incentive to run.

Finally, if the single point of entry plan works as intended, it addresses the global consequences of a failure by limiting the consequences of default to the US holding company. Foreign subsidiaries theoretically will be insulated from the failure and will continue to operate on normal terms. So long as the crisis is limited to the US holding company, or to the holding company and one or more US subsidiaries, the effects of a financial institution's default outside the United States will be much less serious than with Lehman. ${ }^{66}$

\section{B. Potential Problems with Single Point of Entry}

The first concern with single point of entry is simply that regulator won't use it. The decision whether to invoke Title II is entirely discretionary; there is no analogue to the prompt corrective action rules that are designed to force regulators to intervene in a timely fashion when an ordinary bank falls into distress. Single point of entry will make regulators more comfortable intervening than they would be if their only option were to liquidate the SIFI. But regulators will still be tempted to delay. The longer the time lag between the last crisis and the next one, the greater the temptation may be. The Fed and FDIC have scaled up significantly in the wake of the crisis and enactment of Dodd-Frank and might well intervene if a large financial institution were to stumble in the near future. But the state of readiness will inevitably erode with time.

\footnotetext{
66 US and UK regulators have attempted to signal their confidence in the likely effectiveness of this approach through a joint statement endorsing the general framework. See Martin J. Gruenberg (chairman, FDIC) and Paul Tucker (deputy governor, financial stability, Bank of England), "Global Banks Need Global Solutions When They Fail," Financial Times, Op-Ed, December 10, 2012.
} 
And regulators are particularly unlikely to invoke Title II if the crisis affects numerous SIFIs rather than one or two, as in $2008 .^{67}$

Second, even if regulators are willing to intervene, single point of entry could prove problematic if one or more of the SIFI's subsidiaries is deeply insolvent. Although the FDIC has considered ways of down-streaming capital and liquidity to troubled subsidiaries, capital and liquidity alone may not be enough to solve the problems. The risk of subsidiary-level complications could be particularly acute if there are problems with a non-US subsidiary. US regulators would not have any control over the restructuring or liquidation of a non-US subsidiary.

A third problem stems from the prospect that, if SIFIs were left to their own devices, they might have very little long-term holding company debt left when the time came to effect a single point of entry restructuring. Because the long-term holding company debt will be written down in a restructuring, whereas other debt will be protected, holding company debt may become more costly and subsidiary debt comparatively cheap. Other things equal, SIFIs might therefore shift away from long-term holding company debt, leaving too little to recapitalize the SIFI effectively if it fell into financial distress.

Regulators are of course well aware of these incentives; they have responded by mandating that SIFI holding companies retain substantial amounts of long-term debt. In November, 2014, the Financial Stability Board (FSB) issued a proposal for imposing new total loss-absorbing capacity (TLAC) requirements on global systemically important banking groups (G-SIBs) that would supplement Basel III regulatory capital requirements. ${ }^{68}$ The Fed is expected to release a proposed rule for U.S. SIFIs in 2015. Even if the restrictions prove effective, regulators will be forced to police yet another dimension of SIFIs' capital restructure. The risk of evasion is especially high given the clash between the SIFIs' incentives and the regulatory objective of ensuring that SIFIs have enough long term debt for an effective recapitalization.

67 Regulators may also be reluctant to intervene if the SIFI houses an important market function. JP Morgan and Bank of New York Mellon, for instance, are intermediaries in nearly every tri-party repo transaction.

68 Financial Stability Board, Adequacy of loss-absorbing capacity of global systemically important banks in resolution, Consultative Document (Nov. 10, 2014). 
With derivatives and other financial contracts, single point of entry creates precisely the opposite problem. Since derivatives and other short-term obligations will be fully protected, SIFIs have an incentive to use more of them. Given the problems with these financial contracts in 2008, the added incentive to use fragile forms of financing could have dangerous unintended consequences. To be sure, the risks are mitigated somewhat by the increased clearing and exchange trading of derivatives. But a substantial percentage of derivatives still are not cleared; and with cleared derivatives, the protection may have a dampening effort on the clearinghouses' monitoring incentives.

An additional complication is the uncertainty whether regulators will in fact use single point of entry rather than bankruptcy if a SIFI falls into financial distress, and whether they will put a SIFI's bank into bank resolution rather than protecting its shareholders and creditors. ${ }^{69}$ To invoke Title II, regulators must conclude that the SIFI's failure could cause systemic harm. In many cases, it will not. Derivatives are protected under single point of entry but not in bankruptcy, which may induce derivatives counterparties to run if they are uncertain which resolution mechanism will be used. Creditors of a bank subsidiary will be paid in full under single point of entry but will bear significant losses in a bank resolution, a risk they may pass on to the bank in the form of higher credit costs.

Finally, single point of entry violates the spirit—and arguably the letter—of Title II's liquidation requirement. The new strategy's objective is to reorganize a troubled SIFI through a quick recapitalization. Although it is possible to characterize single point of entry as a liquidation - the SIFI's assets technically are transferred to a new entity, and the old entity is eventually liquidated — the effect is indistinguishable from a reorganization. This could subject regulators' intervention to legal challenge.

69 Paul Kupiec and Peter Wallison emphasize uncertainty concerns in a recent critique of single point of entry. Paul Kupiec \& Peter Wallison, Can the "Single Point of Entry” Strategy be Used to Recapitalize a Failing Bank?, AEI Economic Working Paper 2014-08 (December 3, 2014). 


\section{The Bankruptcy Alternative to Title II}

Although bankruptcy is central to the new synthesis of banking regulation and bankruptcy, and the word bankruptcy appears sixty times (by my count) in the Dodd-Frank Act, Dodd-Frank left the Bankruptcy Code untouched. Lawmakers steered clear of bankruptcy for political reasons, not because they thought that the bankruptcy laws are just right in their current condition. ${ }^{70}$ Indeed, advocates of the Dodd-Frank Act argued that bankruptcy is inadequate to the task of resolving the largest troubled SIFI. In my view, defended at length elsewhere, the current bankruptcy rules are far more effective than critics (and the conventional wisdom) suggest. ${ }^{71}$ But in several areas, such as the special privileges given to derivatives and other financial contracts, the current rules undermine bankruptcy’s effectiveness.

The discussion that follows begins by critiquing the current treatment of derivatives and other financial contracts. I then describe Chapter 14, the most comprehensive recent package of proposed bankruptcy reforms, both as initially proposed and as modified to authorize a quick sale modeled on Title II's single point of entry strategy.

\section{A. Bankruptcy's Flaw: The Safe Harbors for Derivatives and Repos}

Over the past thirty years, regulators have steadily expanded a set of exceptions for derivatives, repos and other financial contracts from a variety of core bankruptcy provisions. ${ }^{72}$ The automatic stay prevents ordinary creditors from cancelling their contracts or seizing collateral from a financial institution that has filed for bankruptcy. If the debtor gave new collateral to a creditor or made a large payment shortly before bankruptcy, it may be able to retrieve these assets in bankruptcy. Derivatives and repo counterparties are not subject to any of

70 The sponsors of the Dodd-Frank Act apparently were reluctant to include bankruptcy changes because bankruptcy comes within the jurisdiction of the Judiciary Committee, whereas financial reform is overseen by the Senate Banking and House Financial Services committees.

71 E.g., Ayotte \& Skeel, supra note

72 The "safe harbors" are described in detail in Skeel \& Jackson, supra note 
these provisions. They can cancel their contracts and sell any collateral they hold whenever they wish.

Although a variety of justifications have been advanced for the departure from the ordinary rules, the principal rationale was that the impeding derivatives counterparties' ability to exit their contracts and re-hedge their position could jeopardize the financial stability of the counterparties themselves. Permitting the counterparties to exit their contracts would reduce the risk that a financial institution's failure would cause systemic harm. The 2008 crisis revealed a serious shortcoming of this rationale: the safe harbors can make it impossible for a financial institution to halt its deterioration even briefly, thus exacerbating the effects of its financial distress. ${ }^{73}$ They also make harder for a troubled institution to arrange for sales or other distributions of its assets in bankruptcy, since counterparties cannot be prevented from fleeing before the sale takes place. The safe harbors also have deleterious ex ante effects, diminishing the counterparties' incentive to monitor the debtor and increasing a financial institution’s incentive to use this form of funding rather than less fragile sources of funds.

The most promising response to these concerns is to partially reverse the safe harbors. ${ }^{74}$ Fully reversing the safe harbors, and imposing an automatic stay of potentially unlimited duration, would sharply increase counterparties’ incentive to run when a SIFI encountered financial distress. A counterparty that failed to exit before bankruptcy could be trapped in the bankruptcy process. Although even a brief stay would increase the incentive to run, the effect would be less dramatic. Title II provides a one day stay for derivatives, which is one plausible approach; a somewhat longer stay—such as three days—seems preferable, given the difficulty of making an immediate decision which derivatives portfolios to assume and which to reject. ${ }^{75}$ Although even this seems too short to some, a short stay should prove sufficient for a financial institution that prepares for its bankruptcy before filing (unlike Lehman Brothers, which made almost no advance preparation for its bankruptcy.)

\footnotetext{
73 See, e.g., id.; Darrell Duffie \& David Skeel, A Dialogue on the Costs and Benefits of Automatic Stays for Derivatives and Repurchase Agreements, in BANKRUPTCY NOT BAILOUT, supra note _.

74 The arguments in this paragraph are defended more fully in Skeel \& Jackson, supra note _.

75 Id. at 184-85.
} 
The calculus is somewhat different for repos, which are often very short term and function like secured loans. If the collateral for the repo is treasury bills or other liquid securities, the risk of disruption is limited, even in the absence of a stay. If the collateral is mortgage-backed securities or other illiquid assets, however, as with Bear Stearns and Lehman, the absence of a stay may lead to fire sales as the debtor's counterparties sell the collateral. Repos with illiquid collateral should therefore be subject to a stay. ${ }^{76}$

Mark Roe and Stephen Adams have recently advocated an additional change to the treatment of derivatives in bankruptcy. ${ }^{77}$ They argue, persuasively in my view, that a debtor should be permitted to retain or sell its entire portfolio of a particular derivatives product. Thus, the debtor could sell its portfolio of interest rate swaps or foreign exchange derivatives as a single package. Under existing law, a debtor often enters into a master agreement with a particular counterparty, and may include different derivatives products in the same agreement. If a buyer wished to buy the debtor's interest rate swaps, for instance, but not its other derivatives, the debtor could not easily preserve and transfer only that portion of its derivatives portfolio. Under current law, the debt might need to transfer derivatives counterparty by counterparty, or simply transfer its entire portfolio. Permitting the debtor to assume and sell its derivatives by product line could significantly enhance the debtor's ability to arrange sales, since buyers might be more interested in a particular derivatives product than the debtor's entire derivatives book.

\section{B. The Chapter 14 Proposal}

Starting in 2009, a working group at the Hoover Institution devised a set of proposals that are designed to make bankruptcy better able to handle the financial distress of large financial institutions. ${ }^{78}$ In addition to safe harbor reforms similar to those described above, the initial

\footnotetext{
76 This would entail rolling back the extension of the repo safe harbor to illiquid collateral in 2005, and also amending the safe harbor for securities loans (which arguably protected repos based on mortgage-backed securities even before 2005). Id. at _; Edward R. Morrison, Mark J. Roe \& Hon. Christopher S. Sontchi, Rolling Back the Repo Safe Harbors, BUS. L. (2014).

77 Mark J. Roe \& Stephen Adams, Restructuring Failed Financial Firms in Bankruptcy: Learning from Lehman, YALE J. on REG. (forthcoming, 2015).

78 Thomas Jackson outlines the original Chapter 14 proposal in Jackson, supra note _, at 25.
} 
Chapter 14 proposal included a variety of other changes. I briefly describe several of the most important proposals in original Chapter 14 in this section; in the section that follows, I take up the group's subsequent proposal for a bankruptcy analogue to the FDIC's single point of entry strategy. ${ }^{79}$

Start with the role of regulators. In an ordinary Chapter 11 case, the regulators' ability to participate is quite constrained. Perhaps most importantly, they cannot initiate the bankruptcy case. The Chapter 14 proposal would explicitly authorize regulators to file an involuntary bankruptcy case against an insolvent financial institution that was of sufficient financial size; ${ }^{80}$ and it would give regulators standing to appear and be heard on any issue in the case. Although regulators have traditionally been slow to take action, this proposal would enable them to file a case if managers failed to do so, and it provides a mechanism for tapping the information regulators have as a result of their ongoing supervisory role. In addition, it ensures a voice for systemic consequences in the bankruptcy proceeding.

Chapter 14 also would alter bankruptcy's debtor-in-possession financing provision to permit the debtor to make immediate, partial payments from any new financing to creditors (such as derivatives counterparties) with time sensitive claims. If the initial payment gives these creditors more than other general creditors eventually receive, the difference could be clawed back. But any clawback would occur much later, after the initial crisis had passed. ${ }^{81}$

A third innovation of Chapter 14 is its proposed judicial framework. Under Chapter 14, the case would be overseen by a federal district court judge selected by the chief judge of the federal court of appeals from a panel of judges with financial expertise. This would address any concerns about independence or jurisdictional scope. Chapter 14 also would explicitly authorize the judge to make use of special masters if he wished to bring additional expertise into the case.

79 The discussion that follows draws from Thomas H. Jackson \& David A. Skeel, Jr., Dynamic Resolution of Large Financial Institutions, 2 HARV. BUS. L. REV. 435 (2012).

80 The Chapter 14 proposal is limited to financial institutions with at least $\$ 100$ billion in assets.

${ }^{81}$ For a similar proposal, see George G. Kaufman, A proposal for efficiently resolving out-of-the-money swap positions at large insolvent banks, 9 J. BANKING REG. 3. 
If fully implemented, Chapter 14 would make a number of other adjustments as well. Chapter 14 would remove the outdated exclusion of brokerage operations from Chapter 11, for instance, and would permit insurance companies to file for bankruptcy.

Critics of Chapter 14 have questioned whether Chapter 14 would prove effective for the largest SIFI's, arguing that a much more robust source of funding would be needed and questioning whether a negotiated resolution of a SIFI's financial distress would work. ${ }^{82}$ In part in response to these concerns, the Chapter 14 group developed an alternative resolution strategy that is closely analogous to the FDIC's single point of entry innovation. Since that proposal has subsumed the original proposal, I turn to it now, before providing a fuller assessment.

\section{The Quick Sale Strategy for SIFIs in Bankruptcy}

Under the most recent Chapter 14 proposal, the holding company of a troubled SIFI would file for bankruptcy and immediately propose under section 363 to transfer its assets and short-term liabilities to a newly created corporation, leaving its stock and long-term debt behind. ${ }^{83}$ Unlike with an ordinary section 363 sale, which usually includes an auction period lasting at least thirty days, the new Chapter 14 proposes that the bankruptcy judge approve or disapprove the sale within two days, after notice to the holding company’s largest creditors. The transfer would quickly recapitalize the debtor, much as with single point of entry under Title II.

In theory, a bankruptcy court could approve a quick sale that took this form under current bankruptcy law, although the parties could not be certain in advance that the judge would agree

82 Stephen Lubben is among those who have voiced concerns of this kind. Stephen J. Lubben, "Resolution, Orderly and Otherwise: B of A in OLA," University of Cincinnati Law Review 81 (2012): 485, 517 (arguing that the "key difficulty" with Chapter 14 "rests on funding," and concluding that "something like” the Title II funding mechanism "is a prerequisite to a viable resolution authority"). Also see Stephen J. Lubben, "What's Wrong with the Chapter 14 Proposal," New York Times, April 10, 2013 (questioning "the dubious assumption in Chapter 14 that private debtor-in-possession financing will be available in times of financial distress, especially in the size a large financial institution would need”), http://dealbook.nytimes.com/2013/04/10/whats-wrong-with-the-chapter-14proposal/?_r=0.

83 See Randall D. Guynn, Framing the TBTF Problem: The Path to a Solution, in Across the Great Divide: New Perspectives on the Financial Crisis (Hoover Institution Press 2014) (John B. Taylor and Martin Neal Baily, editors); John Bovenzi, Randall Guynn \& Thomas Jackson, Too Big to Fail: The Path to a Solution (Bipartisan Policy Center, May, 2013). 
to act so quickly. Even if judges were willing to give or withhold their approval quickly, however, three potential problems could stymy such a sale under current law.

One potential problem is the derivatives safe harbors. Under current U.S. bankruptcy law, there is no stay at all on derivatives, as we have seen. Because the holding companies of most American SIFIs do not have significant derivatives portfolios, the absence of a stay on holding company derivatives is not as problematic as it might initially seem. The more pressing issue is the absence of a stay on termination of derivatives held by the SIFI's subsidiaries, especially commercial banking subsidiaries. Of particular concern are so-called cross-default provisions - that is, provisions in derivatives and other contracts that have been entered into by a SIFI holding company's affiliates that give the affiliate's counterparties the right to terminate their contracts if the holding company defaults or files for bankruptcy. Even if U.S. lawmakers were to enact legislation preventing affiliate counterparties from terminating their contracts, the U.S. law would not be binding in other countries; the creditors of a non-U.S. affiliate (such as Lehman's U.K. subsidiaries) might therefore terminate their derivatives if the holding company filed for Chapter 11, even if U.S. law prohibited the counterparties of U.S. affiliates from terminating.

In late 2014, the International Swaps and Derivatives Association promulgated the ISDA 2014 Resolution Stay Protocol, which provides a partial contractual solution to the cross-default problem. ${ }^{84}$ By agreeing to adhere to the ISDA Protocol, a financial institution commits to honor the restrictions on its default and termination rights that are imposed by the resolution framework that governs a parent or affiliate of the counterparty with whom it has contracted. ${ }^{85}$ The ISDA Protocol also covers U.S. bankruptcy proceedings, but in a more limited fashion than with Title II and other bank resolution regimes. The Protocol prevents the counterparties of an affiliate from terminating their derivatives for two business days after a Chapter 11 filing, but does not apply to counterparties of an entity that itself files for bankruptcy.

${ }^{84}$ ISDA 2014 Resolution Stay Protocol (Nov. 4, 2014).

85 Attachment to the ISDA 2014 Resolution Stay Protocol, section 1(a)(i)(A). 
In its current form, the ISDA Protocol only partially addresses the need for a stay on cross default provisions in the context of a quick sale. The Protocol's first limitation is simply that it does not apply unless a financial institution voluntarily agrees to adhere to the Protocol. The Fed and FDIC can close this gap by threatening to take enforcement action against any SIFI that refuses to agree to the Protocol's strictures, and they have already essentially done this. ${ }^{86}$ But institutions over which bank regulators have less authority may evade the reach of the Protocol. More importantly, the absence of a stay on an affiliate's counterparties if the affiliate itself files for bankruptcy could prove to be a serious limitation. If it is necessary to put both the holding company and a troubled subsidiary into bankruptcy, and the subsidiary has a significant derivatives portfolio, the Protocol will not prevent counterparties of the subsidiary from terminating their contracts. The Protocol may thus prove helpful in simple quick sale casescases in which only the holding company needs to file for bankruptcy - but not in messier cases. To more fully close the circle, lawmakers need to reverse the existing derivatives safe harbors.

In addition to a more complete stay on derivatives, a second adjustment that would be needed is a provision assuring that any licenses that are transferred in the initial sale would continue to be valid, so that the company did not risk a disruption in its ability to do business as a result of the sale. Although bank regulators may be able to ensure the continuity of banking charters even under existing law, an explicit statutory protection of existing licenses would remove the risk that a license might be terminated when the holding company transferred its assets to a new entity as part of a quick sale resolution. ${ }^{87}$

The other major issue is funding. As discussed earlier, Title II makes huge amounts of funding available from the US Treasury for a Dodd-Frank resolution. Although the financing provisions of US bankruptcy law are extremely generous by international standards, they rely on financing by private lenders. ${ }^{88}$ There are serious questions whether private financing could be

\footnotetext{
86 The Fed and FDIC have already signaled that they intend to use the living will process to insure that the largest banks are subject to an effective resolution process. See, e.g., Joint Press Release, Board of Governors of the Federal Reserve System and Federal Deposit Insurance Corporation, Agencies Provide Feedback on Second Round Resolution Plans of 'First-Wave' Filers (August 5, 2014) (available at: https://www.fdic.gov/news/news/press/2014/pr14067.html).

87 The proposed legislation currently pending in Congress includes a provision that would protect existing licenses.

88 The rules for debtor-in-possession financing are set forth in 11 USC Sec. 364.
} 
raised quickly enough in the midst of a SIFI’s distress to satisfy its liquidity needs. Many commentators who have followed the bank resolution discussions do not believe that it could be. Although I agree that at least limited access to public funding is needed, a SIFI's existing funding options seem much more substantial, and its liquidity needs less extensive, than is often recognized. Given the centrality of the funding issue, it warrants separate, more extensive discussion.

\section{Funding a SIFI Bankruptcy ${ }^{89}$}

Start with the SIFI's likely access to private funding. The new entity created by the quick sale will be a much better candidate for funding than the pre-bankruptcy SIFI, since it will have left its long-term debt behind, with the expectation that much or all of the debt will be converted into equity in the new entity. It is possible that this cleansing of its capital structure would enable the new entity to very quickly arrange funding from private lenders, especially if the SIFI arranges the funding in advance. Because the new entity will not be in bankruptcy, the funding would not even require bankruptcy court approval. ${ }^{90}$

The magnitude of the SIFI's financing needs may also be manageable. If the new capital and liquidity requirements imposed by Dodd-Frank and other new regulatory efforts are at all effective, a SIFI's capital and liquidity condition may be better when it fails than would have been true in previous years. "Better” doesn’t mean good, of course. But SIFIs might not be quite so far gone when they file for bankruptcy in the new regulatory order, particularly if they think that regulators may otherwise take over the SIFI and put it in Title II resolution.

The quick sale itself also should further limit the SIFI's initial liquidity needs. The quick sale is quite similar to a prepackaged bankruptcy in this regard. ${ }^{91}$ Because prepackaged bankruptcies quickly recapitalize the troubled company, they require much less DIP financing

89 The issues discussed in this section are explored at greater length in David A. Skeel, Jr., Financing a SIFI Bankruptcy, in MAKING FAILURE FEASIBLE (forthcoming 2015).

90 The Chapter 142.0 proposal would authorize the debtor to seek bankruptcy court approval if it wished.

91 In a typical prepackaged bankruptcy, a corporation that wishes to restructure its bond debt files its Chapter 11 petition and its proposed reorganization plan at the same time. 
than other Chapter 11 cases. SIFIs are quite different than the companies that generally file prepackaged bankruptcy cases; their liquidity can disappear much more quickly, and liquidity is central to their business model. ${ }^{92}$ But the general pattern should hold true.

It is also important to keep in mind that if the SIFI fell into distress during a period of market wide crisis, as in 2008, and private financing disappeared, the Federal Reserve could fill in the gap. ${ }^{93}$ Although the Dodd-Frank Act restricted the Federal Reserve's emergency lending authority under section 13(3) of the Federal Reserve Act — prohibiting it from making emergency loans to individual institutions-- ${ }^{94}$ the Fed still the authority to create industry-wide lending programs. In the event of market-wide crisis, the Fed could set up an industry-wide borrowing mechanism.

If one were to conclude that an additional form of funding is necessary due to the uncertainty of private-market funding, what form should that funding take? One obvious alternative would be to replicate the funding terms of Dodd-Frank. A troubled financial institution could be given access to Treasury funding in the same or similar amounts. The principal concern with this approach is that it seems to put too much funding at the new entity's disposal. In theory, this need not have distortive effects, but it is impossible to avoid the suspicion that it would. In my view, these concerns counsel in favor of a more carefully calibrated approach.

The most plausible approach might be to explicitly extend the Fed's section 13(3) lending authority to cover an individual SIFI that has filed for bankruptcy and its successor entity. ${ }^{95}$ Fed

\footnotetext{
92 Interestingly, banks do sometimes recapitalize through a prepackaged bankruptcy. Anchor Bancorp Wisconsin Inc. recently did precisely this, recapitalizing its secured debt and its TARP obligations through a prepackaged bankruptcy that took only eighteen days. See, e.g., Brian D. Christiansen, Van C. Durrer II \& Sven G. Mickisch, The Use of Pre-Packs in Bank Restructuring and M\&A, Financier Worldwide (Jan. 2014).

93 At least under existing law or under the Subchapter V proposal that was recently approved by the House. The Toomey-Cornyn legislation introduced in the Senate in late 2013 would preclude the federal government from providing financing in connection with a SIFI restructuring.

94 Dodd-Frank Act $\S 1101($ a)(extraordinary loans must be part of a "program or facility with broad-based eligibility”).

95 This would require a partial shift from the current rule that the Fed is only permitted to adopt industry-wide emergency loan programs; but a requirement that the SIFI file for bankruptcy before the Fed could authorize funding might make it more palatable.
} 
lending is limited to financial institutions that are solvent and are capable of providing adequate collateral, and is only available if the Fed determines that the loan is needed to avoid systemic harm. ${ }^{96}$ The new financial institution that acquired a troubled SIFI's asset should be able to meet both requirements, but a troubled financial institution that used the ordinary bankruptcy process could not, since it would almost certainly be insolvent. As a result, access to the funds would be tightly constrained. The risk of a disguised bailout would be significantly lower than with OLFstyle liquidity.

The systemic harm prerequisite to funding under section 13(3) would effectively limit governmental funding to bankruptcies of the largest SIFIs, but this is as it should be. The ordinary bankruptcy liquidity options should be adequate for effective resolution of financial institutions that are not systemically important.

The Federal Reserve backstop isn't foolproof. The presence or absence of adequate security is to some extent in the eye of the beholder, especially with a complicated financial institution whose assets are not easily valued. The Fed could manipulate access, much as it is thought by many to have manipulated its emergency lending powers in 2008. But it is subject to significantly more constraints than OLF-style funding.

If the FDIC took a more assertive role in facilitating bankruptcy funding, it could prearrange a source of liquidity even in the absence of formal legislative authority such as an amendment to the Fed's emergency lending powers. Under the systemic risk exception to the ordinary bank resolution rules, the FDIC has broad authority to provide funding for a commercial bank subsidiary that it has put in receivership. ${ }^{97}$ As Howell Jackson has pointed out, this authority could be used to inject liquidity into a SIFI's commercial bank subsidiary if the bank were put into receivership as regulators put the holding company into bankruptcy. The FDIC could ensure its availability for nonbank subsidiaries through a framework of guarantees

\footnotetext{
${ }^{96}$ Extending the Fed's discount window would be an alternative strategy. The principal difference between $\S 13(3)$ lending and the discount window is that discount window loans are available even in the absence of systemic risk concerns.

9712 U.S.C. 1823(c)(4)(G)(authorizing the FDIC to "take other action or provide assistance ... as necessary to avoid or mitigate [serious adverse effects on economic conditions or financial stability]" if the Fed, Treasury and FDIC agree that there is an emergency].
} 
by the SIFI's holding company, commercial bank and nonbank subsidiaries. ${ }^{98}$ The principal limitation of the funding, as with an expansion of the Fed's emergency lending powers, is that it is only available for institutions whose failure could produce a systemic crisis.

Overall, the problem of ensuring adequate funding for a quick sale in bankruptcy seems more tractable than critics have contended. It is plausible that a troubled SIFI could arrange financing even as things currently stand. The FDIC could provide an additional source of funding for a SIFI, at least for SIFIs that truly are systemically important, even if Congress does not amend the Fed's emergency lending powers.

\section{Is the New Regulatory Synthesis Coherent?}

In the final substantive Part of this chapter, I take a step back, and briefly consider how the major pieces of the new regulatory synthesis fit together. I focus first on the relationship between Title I and Title II of the Dodd-Frank Act, and then on the more problematic relationship between Title II and bankruptcy.

\section{A. Tensions Within the Dodd-Frank Framework}

Dodd-Frank has come in for criticism as 1) needlessly complex and 2) internally incoherent. The first part of this criticism—needless complexity-- would be hard to deny. The Volcker Rule, which bans most proprietary trading by commercial banks, is hundreds of pages long. Even before regulators finally released the final rule, many of the largest banks had added regulatory compliance officers whose primary responsibility is managing Volcker Rule. The regulatory burden might be justified if the Volcker Rule enhances the safety of the largest banks, but there is little reason to believe that it will. It and other new regulatory obligations have steeply increased the compliance burdens of all banks, not just the largest institutions. Ironically,

98 Under Howell Jackson's proposal, the commercial bank would guarantee the holding company's obligation to serve as a source of strength for a troubled nonbank subsidiary, and the holding company would then commit to indemnify the commercial bank for any losses on the guaranty. 
Dodd-Frank's complexity solidifies the preeminence of the largest banks, since they enjoy economies of scale in handling regulatory compliance costs.

The second, internal incoherence claim is more subtle and more directly relevant to my concerns in this chapter. Prominent banking consultant Karen Petrou Shaw has argued that the regulatory objectives of Titles I and II of Dodd-Frank are directly at odds with one another. "On the one hand," as a New York Times columnist summarized her diagnosis, Title II "is very clear that if a big bank becomes insolvent, there can be no taxpayer bailout. It must be wound down, just like any other bank." 99 Yet, as they implement Title I, regulators "are adding a host of special Too Big to Fail capital requirements and rules. 'They are acting as if these institutions are still too big to fail. The two thrusts are incompatible."”

Before asking whether these two key titles can be reconciled, let me first note a tension within Title I itself. Although Title I's designation process and capital requirements can be seen as entrenching Too Big to Fail, several other features have an opposing thrust. Regulators can refuse to approve acquisitions by the largest banks, for instance, and even force them to downsize; ${ }^{100}$ the Volcker Rule fits the break up theme. Whether or not the tension was intended, it reinforces the corporatist tendencies of the Dodd-Frank Act. ${ }^{101}$ Absent a successful populist legislative intervention, the size restrictions and Volcker Rule will serve as leverage to reinforce the implicit partnership between the government and the largest banks. The TBTF orientation of Title I will be reinforced rather than undermined.

Absent single point of entry, the tension between Titles I and II—Petrou's particular concern—almost certainly would have been resolved the same way. Regulators would bail out a struggling SIFI rather than risking a messy liquidation under Title II. At least for the largest banks, Title II would be a dead letter. ${ }^{102}$ Although Dodd-Frank prohibits rescue loans to a single institution, as we have seen, regulators could sidestep the restriction by putting an industry wide program in place. Bailouts would be nearly as likely as before the Dodd-Frank Act.

99 Joe Nocera, N.Y. TIMES, Jan. 17, 2012, at A23.

100 Dodd-Frank Act $\S 121$.

101 See SKEEL, NEW FINANCIAL DEAL, supra note _.

102 A catch 22: Title II wouldn't be used for the big banks; yet regulators theoretically could not use it for smaller banks because it requires a finding that failure could cause systemic harm. 
The relationship between Titles I and II looks quite different in a world with single point of entry. Regulators might actually use single point of entry. If single point of entry worked as envisioned, the troubled bank would be recapitalized; it would not receive a 2008-style bailout. The bank would, however, remain nearly as large, and the banking industry would be just as concentrated, as before the single point of entry resolution.

As a matter of semantics, one might still claim that Title II is in tension with Title I, since Title I protects the largest institutions and tries to prevent them from defaulting, whereas Title II is triggered by a looming default. But the regulatory framework really is quite consistent. Title I is the first line of defense, and single point of entry is the backup; there is redundancy, perhaps, but a single objective: Both aim to preserve the current structure of the banking industry.

One can debate whether the current structure is desirable. In my view, the concentration of the U.S. banking industry is problematic, potentially chilling innovation and diminishing the access of small and medium sized businesses to financing. If the largest banks were forced to downsize — or better yet, rewarded for downsizing ${ }^{103}$ — these distortions might be reduced. The current framework is thus problematic, in my view, but it is nevertheless coherent.

The still-awkward relationship between Title II and bankruptcy, by contrast, raises questions of coherence. Once they are identified, both proponents and critics of the new synthesis should agree that at least some of the frictions need to be addressed. These frictions will occupy the rest of our discussion.

\section{B. Frictions in the Title II-Bankruptcy Framework}

\section{Frictions in the Basic Framework}

As noted earlier, the new regulatory synthesis takes a contradictory stance on the relationship between Title II and bankruptcy. The Dodd-Frank Act consistently prioritizes bankruptcy. The living will requirement instructs SIFIs to explain how they can be resolved in

103 The proposed Brown-Vitter legislation, which would impose much higher capital requirements on bank holding companies with $\$ 700$ billion or more in assets, could have something like this effect if it were adopted. 
an orderly fashion in bankruptcy, not Title II; and Title II identifies bankruptcy as the preferred option, regulators are not permitted to invoke Title II unless they conclude that bankruptcy would prove systemically disruptive. Yet Title II explicitly trumps bankruptcy in the new regulatory scheme. If a SIFI files for bankruptcy, bank regulators can invoke Title II and take over the SIFI at any time, displacing the ongoing bankruptcy proceedings. ${ }^{104}$

Frictions also exist at the level of individual provisions. Although lawmakers incorporated a number of bankruptcy provisions into the Title II framework, ${ }^{105}$ Title II is based primarily on the FDIC’s bank resolution powers. Like bank resolution, but unlike bankruptcy, Title II imposes a one-plus day stay on derivatives, freezes cross default provisions, and invalidates walkaway provisions — which allow a derivatives counterparty to terminate a contract without making any payments to the SIFI debtor, even if the debtor is in the money. ${ }^{106}$ Bankruptcy does not give a SIFI debtor any of these protections.

The treatment of SIFI managers is similarly divergent. Although the absence of a stay on derivatives reduces the benefits of bankruptcy, the managers of a troubled SIFI still may be willing to plan for and use bankruptcy, since they will continue to run the business at the outset of the bankruptcy case; the managers can effectuate their plans. Yet the managers cannot be certain that the resolution will in fact take place in bankruptcy. Regulators can move the proceedings to Title II. ${ }^{107}$ If they do, the top managers lose control, will be promptly replaced, and may have their pre-default compensation clawed back. ${ }^{108}$ Given the threat of Title II, managers may postpone bankruptcy and perhaps resist a bankruptcy filing altogether, much as Lehman Brothers did.

What could be done to resolve these frictions? One obvious step is to better coordinate the two frameworks. At the very least, lawmakers should amend the bankruptcy laws to provide the same limited stay and other protections in bankruptcy that a SIFI is given in Title II. Although this would not reduce counterparties’ incentives to run, it would not substantially

\footnotetext{
104 Dodd-Frank Act § 208.

105 The most obvious illustration is the incorporation into Title II of significant portions of the preference, fraudulent conveyance and setoff rules that apply in bankruptcy.

106 Dodd-Frank Act $\S 210(c)(10)(B)(o n e$ day restriction on ipso facto clauses); $§ 210(c)(8)(F)$ (walkaway provisions).

107 Id. 208 (Title II displaces any prior bankruptcy case).

108 Id. § 206 (managers removed); § 210(s)(clawback).
} 
increase the likelihood of runs; and the stay would enhance bankruptcy's effectiveness in halting a run and would facilitate more effective resolution in bankruptcy.

The same logic might counsel in favor of either removing the manager penalties from Title II or adding them to bankruptcy, so that managers would receive the same treatment under both frameworks. Here, however, I would propose a different solution. Rather than equalizing the treatment, regulators could commit to leave a SIFI that has filed for bankruptcy in bankruptcy. From this perspective, bankruptcy’s softer landing might strengthen managers’ incentive to prepare and file for bankruptcy rather than waiting for regulators to intervene. ${ }^{109}$

\section{Frictions created by single point of entry}

The frictions we have considered thus far have been created by the Dodd-Frank framework itself. The single point of entry and bankruptcy quick sale strategies have introduced still another set of potential frictions. Under single point of entry, the bondholders and other long-term creditors of a SIFI's holding company will bear the burden of the SIFI's recapitalization. By contrast, if regulators put a SIFI's bank subsidiary in Title II, bondholders of the bank, rather than holding company bondholders, may bear much of the cost of the restructuring. The incidence of the burden will be very different, depending on the resolution technique that regulators employ. One potential cost of the uncertainty may be difficulty issuing new bond debt at either the holding company or the subsidiary level as a SIFI's condition declines, since it is not clear which will bear the losses in the event of a default. Both sets of creditors need to assume that they will bear the brunt of the restructuring.

I do not think there is a fully satisfying solution to this problem. The Federal Reserve is expected to mandate that bank SIFIs maintain adequate buffers of long term debt, which theoretically will set a floor on the holding company's and banking subsidiary's issuance of long-term debt. If bank regulators are clear about what to expect if they intervene, they can further reduce the amount of uncertainty. Significant uncertainty is likely to remain, however. And the strategic incentives created by single point of entry-to issue debt at the entity that is

109 I proposed a somewhat analogous strategy for bank resolution many years ago. Skeel, Law and Finance, supra note 
less likely to be restructured—will require bank regulators to actively monitor SIFIs' capital structure. Given the mismatch between regulators' objective of ensuring an adequate buffer of longterm debt, and the SIFI's incentives-minimizing its debt costs by raising money at entities whose debt will not be restructured—SPOE will invite the kinds of regulatory arbitrage that have long bedeviled capital regulation.

The difficulty SIFIs may have raising funds as their financial condition deteriorates does have one silver lining: it will strengthen their managers' incentive to file for bankruptcy sooner than might otherwise be the case-perhaps soon enough to enhance the prospects for an effective resolution.

\section{Conclusion}

Over the past five years, the Dodd-Frank Act has reshaped the relationship between banking regulation and bankruptcy. In one sense, it dramatically expanded the reach of bankingstyle resolution, since the legislation gives bank regulators resolution authority over bank holding companies and investment banking operations that previously were subject solely to bankruptcy in the event of financial distress. But the Act also incorporates bankruptcy into bank regulation, as with the requirement that SIFIs' living wills outline how the SIFI could be resolved in an orderly fashion in bankruptcy.

The more effective the bankruptcy process is, the less necessary Title II will be. Even in its current configuration, bankruptcy law is a much better resolution mechanism than many commentators have recognized. With a handful of additional changes-most importantly, the reintroduction of a stay on derivatives - bankruptcy law would be a credible resolution strategy for nearly any SIFI. Given the benefits of bankruptcy as compared to Title II, this is a consummation devoutly to be wished. Title II will work best if it is available if necessary, but rarely or never used in practice.

Only in passing have I addressed the debate over whether the largest banks should be broken up. If this were actually to happen, my principal recommendations would not change. 
As noted earlier, I personally would favor a less concentrated banking industry, due to the detrimental effects of concentration on innovation and lending to small and medium-sized businesses. But I leave that particular debate for another day and other work. 